cavities of the vesicular parts of the rock wcre often filled by calcite or hematite.

The apparent absence of any cone or tuff deposit, the compact and columnar structure of the rock, and the vertical position of the columns, seemed to show that the whole had been originally one continuous sheet of submarine lava-streams, which had been subsequently elevated and cut up by the waves into the screral islands-a conclusion which was supported by two other circumstances: the form of the islands and the shallow intervening depths (6 to 9 fathoms).

It is noteworthy that several of the islands sloped away gradually west-south-west to south-west, a direction coinciding with that of the submarine slope in this part of the Formosa Channel. From this circumstance it would seem that the succession of lava-streams flowed in a south-west direction, and that their source lay in the north-east portion of the group.

I7, Woodlane, Falmouth, $\Lambda$ pril i I

II. B. GUPPY

\section{A New Bird in Natal}

Some months aro, Mr. Fereirra, a member of my congregation, informed me that he harl shot some time previously a bird in the early morning which neither he nor any of his neighbours hat seen before. From his description of it I concluded that it probably belonged to the goat-suckers, and on examination of the skin I find that the supposition is correct.

A day or two ago he brought the skin to me: it had been stretched against the wall of bis room to display its plumage to the greatest advantagc. The measurements which 1 give cannot therefore be perfectly accurate. One of its long plumes has been broken by a pellet, but otherwise the skin is in tolerably good preservation, and I trust that it may be well stuffed and set up, for the bird is certainly not mentioned in the first edition of layard's "Birds of South Africa," nor yet in any of the books or catalogues in my possession, and the bird is in itself so very remarkable that one cannot help thinking that it would have been described in the boolss I have had it been known. I will deposit the skin in the Natal Museum, Pietermaritzburg. The bill is that of a goat-sucker, strongly fenced with strong hairs. The length of the boty from tip of the bill to the insertion of the tail is 6 inches; length from tip of bill to tip of tail, I $x$ inches; length between tips of wings-probably stretched too much-24 inches.

The colour is the usual brown of the family-lyars on the tail of brown black, and mottled bars of light and dark brown feathers, eight in number, the longest on the outside of the tail.

Wing: : Primariæ, 9 in number.

Length of the ist feather, $7 \frac{1}{\mathrm{~g}}$ inches.

" and " about an inch shorter. 3rd , shorter than second; the following three about the same length as the $3 \mathrm{rd}$. Length of the 7 th feather, $7 \frac{1}{2}$ inches.

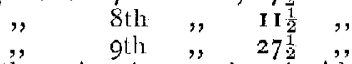

The first seven of the primarice arc tipped with white, the and and 3 ril rather broadly, the ist scarcely. The 8th becomes greyist towards the tip, and the ribs of the $7^{\text {th }}$ and 8 the aro brown, while the others are black. Two-thirts of the length of these feathers are black ; but a band of white, narrower on the first and increasing to about 3 inches broad on the $81 h_{1}$ feather, extends along the roots and middle of them, and crosses over to the oth long feather, which, for $2 \mathrm{I}$ or 22 inches, is of a dullish silver-gray. The secondariae are tipperd with white, with tho exception of the Ist and 2nd, which only give inclications of being so; they are generally black-brown, with markings of light brown. There is a reddish ring around lower back part of the neck.

The breast is light gray, generally with light brown markings in bands.

Its feet are those of a groat-sucker, but on comparing the foot of the cuprimulgus europazts, as drawn by $V$ an der Hoeven (vol. ii, plate 7, Fig. 9, ed. I858) I find the teeth of the comb of the middle toe much broader and stouter than that of the former. There are only four teeth, with a smaller or false one at the root of the nail. The length of the nail is about onecighth of an inch, and the breadth of tooth is therefore about one-sixteenth of an inch.

This bird is cvidently very closely related to the pennant-winged night jar, or long-shafted goat-sucker (Macrodipteryx africanus); but the markings are very different, and the long-shafted feathers are not more than 7 inches long, while those of this bird are more than 27 inches in leugth, and they do not display any inclination to form a long nakcd shaft, but are clothed or webbed on both sides from the root to the tip.

It is very singular that this bird should only have become known in this district in 1884 . The farmers are close observers, as also are the Kaffirs, but no one has ever seen it. It is the more singular since it was shot on a farm that has been long occupied, and that by a farmer who in his younger days was accustomed to help collectors of birds for our European museums. Perhilps the long and severe droughts, said to prevail this year in the interior, may account for its presence in Natal.

Pastorie, Grey Town, Natal, March 2 JAMES TURNBULI

\section{T. E. VON SIEBOLD}

CARL TIIEODOR ERNST VON SIEBOLD was born at Würzburg, in Bavaria, on February 16,1804 . His brother was the well-known traveller and philologist. Carl was brought up chiefly, under the superintendence of his father, for the medical profession, and he carried on a practice for a few years as a physician at Heilsberg and Königsbers. In 1835 he received the appointment of Master of the Lying-in Hospital at Dantzic. Early in his life he showed an interest in zoology, and in 1840 he removed from Dantzic to Erlangen, where he taught comparative anatomy, zoology, and veterinary medicine. In 1845 he was appointed Professor of Zoology at Friburg, and shortly afterwards he made a prolonged sojourn on the Adriatic. At this time he worked with immense zeal and ardour at the anatomy of the marine invertebrates, and as the result of this work and his lectures combined he commenced the elaboration of his well-known "Lehrbuch der vergleichenden Anatomie der Wirbellosen Thiere." In his preface to this work, which has been translated into English and French, he insisted on the importance of a knowledge not only of the minute anatomy but also of the devclopmental stages of the forms described. Generous aid in the completion of this at the time most excellent treatise was given to him by $\mathrm{C}$. Vogt, H. Stannius, A. Krohn, H. Koch, and A. Kölliker, and in I 849 he founded, in connection with the last-named of these eminent biologists, the Zeitschrift fiur wissenschaftliche Zoologie, a journal which has ever held a leading position among the scientific publications of our day, and one which is still known and esteemed wherever zoology is studied.

In 1850 von Siebold was appointed to the Professorship of Physiology in the University of Breslau, and also received the charge of the Physiological Institute of that city.

In 1853 he was appointed Professor of Zoology and Comparative Anatomy in the University of 4 Munich, and Director of the Zoological and Zootonical Cabinet in that city. These positions he filled during the remainder of his life.

Shortly after his appointment to the Munich Professorship he commenced an elaborate series of investigations into the vexed question of "Parthenogenesis," entering on the subject with a belief that facts had been misunderstood; and his treatise on this phenomonon, as found by him to actually exist in bees and moths, was a genuine contribution to science. This work was published at Leipzig early in 18,6 , and was translated by Mr. Dallas the following year into English.

Somcwhat earlier in date he published a memoir on "Tape and Cystic Worms, with an introduction on the Origin of Intestinal Worms," which was deemed worthy of being translated into English, by Prof. Huxley, for the New Sydenham Society. The good that this translation effected by introducing some scientific facts to the notice of our medical men it is not easy to calculate.

In 1858 the Royal Socicty elected him as one of their honorary members. In 1867 he was made a correspond- 
ing member of the Institute of France. There seems little need to enumerate all the honours that were conferred on him during the half century that he was known as one of the distinguished zoologists of Europe.

In the important and indispensable catalogue of Scientific Papers published by the Royal Society, we find a list of over I 30 memoirs ascribed to Prof. Von Siebold.

Failing health during the last few years interrupted this, up to 1874 , steady flow, and Dr. Ehlers undertook much of the labour of editing the Zeitschrift. Those who had a personal knowledge of Von Siebold will remember his pleasant and friendly manners, the readiness with which he placed at the students' disposal all the information in his power, and the visitor to the Zoological Museum at Munich will not soon forget the vast stores, not only collected, but scientifically arranged under the superintendence of Von Siebold.

\section{THE EGGS OF FISHES ${ }^{1}$}

\section{II.}

$\mathrm{T}$ $\mathrm{E}$ condition of the fish-fauna of the various grounds may be estimated to some extent by the number of the floating ova near the surface. We have seen that Sars found the water crowded with the multitude of ova off the Loffoden Islands, where enormous numbers of cod are captured. In our seas no fishing-bank is so prolific, the greatest number of ova occurring on Smith Bank, off Caithness, and the next on the rich grounds off the Island of May-both of which present a great contrast with the meagre supply of eggs of round fishes floating in our own bay. The proportional numbers in each case accord very well with the captures of adult cod in the several areas.

No sight can be more interesting to the naturalist than the surface of the sea, in the condition just mentioned, about the beginning of April. The rough water of the great fishing-grounds--such as off Smith Bank, and somewhat further from land-is enlivened by large groups of gulls, guillemots, and the ubiquitous gannets, apparently feeding on the smaller fishes which have been attracted to the surface by the wealth of food. At short intervals the long dorsal fin of a large killer appears above the surface, and the water behind it is churned into foam by the powerful strokes of its tail ; while a small group of bottle-noses (another kind of toothed whale) is recognised by the noise and foam, as one or more leap from the sides of a huge wave. The tow-net collects large quantities of ova and minute fishes which have just escaped from the egg. It further shows that innumerable minute crustaceans, such as Copepods (e.g. Calanus finmarchicus, Gun., and Temora longicornis, O.F.M.), multitudes of the young, or nauplius-stage, of sea-acorns, Sagitta, and peculiar Annelids (Ioida) are present. It is evident, therefore, that the young fishes are placed in the midst of a rich surface-fauna, the more minute forms of which would readily serve as food.

In the foregoing remarks on the floating eggs of British food fishes, those of the cod, haddock, and whiting, have been chiefly alluded to. We shall now refer to others, either wholly or partially unknown till this year. I have already mentioned that Sars found certain floating eggs mingled with the former on the surface of the sea, and identified the young, after hatching, as gurnards. In the present case the eggs were removed from the adult gurnard, and hatched at St. Andrew's in about a week, so that a further step has been made. The eggs of the gurnard float as buoyantly as those of the cod and haddock, but they are considerably larger. Each has a very distinct oil-globule opposite the germinal area, which generally is directed downwards. Some are of opinion

${ }^{I}$ Introductory Lecture delivered to the Class of Natural History in the University of St. Andrews, on. Novernber 1o, by Prof. McIntosh, LI.D., F.R.S. Continued from p. 536 . that the floating of the eggs of such fishes as we are now considering is due to the oil-globules, but the eggs of several fishes, e.g. those of the salmon, have a larger quantity of oil, and yet they do not float. 'The specific gravity of the eggs is slightly less than that of the seawater; but the precise connection between the floating of the living ova and the sinking of the dead has yet to be made out. Such would form, indeed, a most valuable and interesting subject for investigation at the Marine Laboratory. So easy is it to hatch the eggs of the gurnard that the water in the instance just narrated was not changed. The rapidity with which the development of the embryo goes on in the egg is remarkable, for in 7 or 8 days the young are extruded, whereas in the salmon, for instance, no less than 60 days are required even in a room with a temperature much higher than that of the open air. If the eggs of the salmon are permitted to hatch in an ordinary river, a period of from 95 to 120 days is usually necessary for hatching. The very great difference, therefore, between the marine and freshwater fishes in this respect is apparent.

The only flat fish in which the ova had been found to float was the plaice, which Dr. Malm had examined in the Baltic. In May of this year, however, the eggs of the common flounder in St. Andrew's Bay showed the same feature. They floated buoyantly on the surface of the water. Prof. Huxley at this time having suggested that perhaps the floating or sinking of the ova was a question of temperature, the eggs of this species were used in some experiments. They had been removed from the fish on May 2, and placed in the Marine Laboratory. On the 5th the majority still remained on the surface, those on the bottom having been carried down by the attachment of sand-grains. A number from the surface were placed in a test-tube. After standing an hour the majority were floating on the surface, one or two lay on the bottom, while others rested in mid-water. Placed in a vessel of water at $98^{\circ}$, the eggs exhibited lively movements for several minutes, being carried up and down by the currents, but never remaining at the bottom. The test-tube felt quite warm to the touch, yet the eggs floated, and remained floating, as buoyantly in the warm water as in the cold, so that their floating in the sea is not a question of temperature.

An interesting sequel, further, remains to be told in connection with this experiment, in which the test-tube had been placed aside and forgotten. On May 10, while explaining the matter to Prof. Ewart, he noticed motion in the test-tube, and I found that the eggs which had been raised to a temperature of $98^{\circ}$ had given birth to little flukes, which thus survived the exigencics of their surroundings, both as regards temperature and water. These little creatures are as symmetrical in outline as the young cod or haddock, an eye being placed on each side of the head, while in the adult flounder, as you are all aware. both eyes are on one side (the right or coloured one). The pigment is quite different from that of the young cod, bcing of a peculiar pale olive or brownish yellow by transmitted light, and the cells seem to be less branched. Their motions also diverge from those of the cod, for the little creatures hang head downwards in the water, either perpendicularly or obliqucly, the yolk-sac being on the upper line of the slope. They then move upward, hang as formerly, or slowly descend, repeating these motions frequently. The young cod, on the other hand: dart nimbly about near the surface of the water, and bear themselves quite differently.

But to return to the ova. Before the summer that has just passed, it was not known whother the ova of the turbot, sole, and lcmon-dab-all important and valuable food fishes-floated or sank. Accordingly such fishes were a source of special interest. It was not till the end of June and in July that perfectly ripe turbot conld be procured, and then the small ova were found to float as 